\title{
LUT
}

University

The antecedents of early internationalization: A configurational perspective

Ciravegna Luciano, Kuivalainen Olli, Kundu Sumit K., Lopez Luis E.

This is a Final draft version of a publication

published by Elsevier

in International Business Review

DOI: $10.1016 /$ j.ibusrev.2018.05.002

Copyright of the original publication: (c) 2018 Elsevier Ltd.

Please cite the publication as follows:

Ciravegna L., Kuivalainen O., Kundu S.K. \& Lopez L.E. (2018) The Antecedents of Early Internationalization: A Configurational Perspective. International Business Review, vol. 27, iss. 6, pp 1200-1212. DOI: 10.1016/j.ibusrev.2018.05.002

This is a parallel published version of an original publication. This version can differ from the original published article. 


\section{The Antecedents of Early Internationalization: A Configurational Perspective}

\section{This is an Author's Original Manuscript (AAM) of an article published by Elsevier in International Business Review. Please cite the final published article:}

Ciravegna L., Kuivalainen O., Kundu S.K. \& Lopez L.E. (in press) The Antecedents of Early Internationalization: A Configurational Perspective. Accepted for publication /forthcoming in International Business Review

https://doi.org/10.1016/j.ibusrev.2018.05.002

\section{Authors}

Luciano Ciravegna ${ }^{a d}$, Olli Kuivalainen ${ }^{\text {be }}$, Sumit K. Kundu ${ }^{c}$ Luis E. Lopez $^{d}$

${ }^{a}$ King's College, University of London, The Strand, London, WC2R 2LS, United Kingdom

${ }^{b}$ Alliance Manchester Business School, the University of Manchester, Booth Street East, Manchester M13 9SS, United Kingdom

c College of Business, Florida International University, 448 Mango Building, 11200 SW 8 Street, Miami, FL 33199, USA

d INCAE Business School, Apartado 960-4050, Alajuela, Costa Rica

${ }^{e}$ Lappeenranta University of Technology, School of Business and Management, POB 20, Lappeenranta, Finland 


\section{The Antecedents of Early Internationalization: A Configurational Perspective}

\section{Abstract}

The literature on international business and international entrepreneurship provides multiple explanations for early internationalization. Using fuzzy-set qualitative comparative analysis, this study examines the antecedents of early internationalization for small firms based in a small economy, focusing on entrepreneurs' attitudes toward the economic opportunities available in their domestic market, the risk of internationalizing, and the profitability of entering foreign markets. Three additional antecedents are examined: unsolicited orders, existence of underutilized capacity, and the behavior of competitors. The study uncovers three distinct combinations of antecedents that are equifinally linked to the early internationalization of small enterprises, and contributes to the literature through a multi-causal, configurational approach.

Keywords: early internationalization; antecedents for early internationalization, configurational approach; fuzzy-set qualitative comparative analysis, software 


\section{INTRODUCTION}

Early internationalization can be an important prerequisite for consequent development of the firm. For example, Autio, Sapienza, and Almeida (2000) postulate that the sooner a firm becomes international, the sooner it will grow faster. Hence, understanding why some firms promptly become international new ventures (INVs) or born globals (BGs), while others internationalize more gradually, is important (Jones and Coviello 2005; Oviatt and McDougall 2005; Leonidou et al. 2007; Prashantham 2011).

Despite the number of studies that discuss INVs and BGs (e.g., Baum, Schwens, and Kabst 2011; Cavusgil and Knight 2015; Kuivalainen, Sundqvist, and Servais 2007; Oviatt and McDougall 1994; Rialp, Rialp, and Knight 2005), the antecedents of early internationalization remain a subject of debate among scholars (Armario, Ruiz, and Armario 2008; Baronchelli and Cassia 2011; Cavusgil and Knight 2015; Leonidou et al. 2007; Zucchella et al. 2007). Research has found several antecedent factors explain early internationalization and rapid commitment to international markets, but results are to a certain extent inconclusive. Some authors argue that factors external to the firm, such as the size of the domestic market and the availability of opportunities in other markets, help explain early internationalization (Dimitratos et al. 2004; Fan and Phan 2007; Zahra, Neubaum, and Huse 1997). Armario et al. (2008) found that market orientation, for example, market intelligence generation, is the key to increasing international commitment. Baronchelli and Cassia (2011) found that market knowledge, product innovation, and operating in a niche market increase early international commitment.

Scholars who draw from the entrepreneurship literature underline internal factors, such as the importance of entrepreneurs' attitudes—-for example, whether they perceive foreign markets to be risky or profitable - in shaping firm-level decisions, including when to internationalize 
(Gil-Pechuan, Exposito-Langa, and Tomas-Miquel 2013; Javalgi and Todd 2011; Mitchell et al. 2007; Oviatt and McDougall 2005; Sommer and Haug 2011). This stream has often dominated the papers focusing on INVs and BGs (Zucchella et al. 2007).

The processes of early internationalization seem to be the result of complex interactions (Zucchella et al. 2007). This complexity may partially stem from the fact that studies of earlyinternationalizing firms bring together different theoretical streams of the international business and entrepreneurship literature (Bloodgood, Sapienza, and Almeida 1996; McDougall and Oviatt 2000; Sommer 2010). Most empirical research on firms that internationalize early in their life cycle attempts to establish the relevance of one particular set of explanatory variables through linear causality methods (Kuivalainen et al. 2007; Tuppura et al. 2008; these studies look at the effect of various types of resources or capabilities on timing or type of internationalization). Qualitative studies, however, reveal the timing of internationalization is often the result of the effects of the interaction of multiple causal antecedents (Chandra, Styles, and Wilkinson 2009; Crick 2009; Ojala 2009). For example, the case of an entrepreneur that has unused resources in his firm and internationalizes in reaction to an unexpected order from abroad (Ellis 2011) combines an internal causal antecedent (under-used resources) with an external antecedent (an international business opportunity). This article contributes to the literature by examining the antecedents of early internationalization through a configurational approach, which suits the diverse sets of theories thus far used to explain the phenomenon and its complex nature (Jones and Coviello 2005; Ojala 2009; Ragin 2008).

We contribute to the international business and international entrepreneurship literature by examining the antecedents of early internationalization, using research methods that differ from the conventional linear causality logic, as called for by several leading scholars (Jones et al. 
2011; Tsang 2013; Welch et al. 2011). We use fuzzy-set qualitative comparative analysis (fsQCA) to explore multiple configurations of antecedents that might compel firms to internationalize soon after their inception.

Drawing from the entrepreneurship literature on attitudes and behavior and from studies of export behavior, this study examines three attitudinal antecedents of early internationalization: attitude toward the risk of internationalizing, attitude toward profitability of foreign markets, and limitations imposed by operating in a small domestic market (Cavusgil and Naor 1987;

Omorede, Thorgren, and Wincent 2015; Sommer 2010). It also analyzes the impact of three antecedents that, according to the literature, could affect the time it takes a firm to penetrate its first foreign market, namely, reception of unsolicited orders, availability of underutilized capacity, and competitors' behavior (Dimitratos et al. 2004; Ellis 2011; Fan and Phan 2007; Knight and Cavusgil 1996; Kontinen and Ojala 2011a; Zahra et al. 1997).

The results of this research uncover three configurations of antecedents that lead to early internationalization. Our contribution is precisely to find and explain these causal paths, or configurations of antecedents, which are equifinally linked to early internationalization, though none of the antecedents is, per se, sufficient for such an outcome to occur. To our knowledge, this research is the first attempt to study early internationalization from an equifinality, complex, and asymmetric causality perspective, and responds to calls for more research using this method in management and international business (Misangyi et al. 2017). Through combinatorial lenses, we are able to show that in real life, the causal drivers of early internationalization may be very different for different firms, even within a narrowly defined empirical context, and that fully capturing such drivers may require combining theoretical perspectives. 
This study's structure is as follows: the first section discusses the literature on earlyinternationalizing firms; the second introduces the methods; the third outlines the results; the fourth discusses the results; and the conclusion explores theoretical implications and suggests avenues for further research.

\section{ANTECEDENTS OF EARLY INTERNATIONALIZATION}

Empirical studies provide a variety of possible yet competing explanations of early internationalization (Coviello and Munro 1997; Dimitratos et al. 2010; Fan and Phan 2007). However, the literature shows that irrespective of the contextual situation, certain motives tend to play a seminal role in encouraging small firms to internationalize, such as the desire to achieve extra sales and profits, reduce home-market dependence and the threat of home-market saturation, and respond to unsolicited orders (Leonidou et al. 2007). Furthermore, in earlyinternationalization studies, the fundamental international orientation or entrepreneurial motives, such as risk-taking, are commonly seen as key explanatory factors (Cavusgil and Knight 2015). The antecedents we hereby explore are anchored in three rather different perspectives on the subject: (1) the resource-based view (RBV), which suggests internationalization decisions depend on the resources and capabilities under control of the firm (which can be either internal or external via networks, e.g., Barney 1991; Knight and Cavusgil 2004; Matthews and Zander 2007); (2) the market-based view (MBV), which, drawing from the international marketing literature, posits that firms' internationalization is driven by pressures they perceive in their current markets (e.g., Kamakura, Ramón-Jerónimo, and Gravel 2012) and that general marketbased factors would dominate the decision making (competition and positioning, e.g., Porter 1979); and (3) the entrepreneurial perspective, which, drawing from the entrepreneurship 
literature, focuses on, for example, opportunity identification, attitudes, mindsets, and orientation of the entrepreneur (see, e.g., Andersson 2000; Oviatt and McDougall 2005; Zahra, Korri, and Yu 2005). Our quest is to find out how configurational paths formed from these sets of antecedents lead to internationalization. Leonidou et al. (2007, p. 753) point out that "export stimulation should be seen as the synergistic outcome of a bundle of factors which changes over time and under different conditions." This idea provides support for the contingency argument; for example, when firms' motives and capabilities would be in coalignment with the business environment, they would form a coherent configuration that would lead to the outcome, here internationalization. In their study about the configurational approach's suitability in entrepreneurship, Harms et al. (2009) suggest that conceptual domains of "individual," "resources/structure," "strategy," and "environment" could be relevant for describing new ventures. Taking a cue from this idea, and for parsimony, we focus on a set of antecedents that the literature has identified as important explanations for early internationalization. We acknowledge we do not cover all the possible antecedents, and hope that further work can extend this research by including different antecedents. The logic behind the choice is to consider two key strategic perspectives (RBV and MBV) and then integrate the entrepreneur into the model as well, because the domain of the study is about entrepreneurial SMEs. ${ }^{1}$ Harms et al. (2009) suggest that specifying an a priori configuration approach that is able to capture particular characteristics of the focal firms studied is important. They point out that in the case of new

\footnotetext{
${ }^{1}$ We acknowledge that we do not examine all possible antecedents of early internationalization, such as unique product offering and networks (cf., e.g., Knight and Cavusgil 1996; Cavusgil and Knight, 2015). fsQCA methods suggest using a limited number of antecedents in order to ensure the models are parsimonious and plausible (Ragin, 2008). Note that causality in fsQCA is not exclusionary, because it works with fuzzy sets. In other words, what we discuss here is empirically and methodologically valid, and we believe it is theoretically interesting. Other combinations of different antecedents could lead to the same outcome. To test this sort of causality, however, it would be best to have a different research design that controls alternative causality for at least some of the antecedents we examine here (e.g., firms based in a large economy, none of which received unsolicited orders), and focus the model on other antecedents and their combinatorial effects (e.g., networks, product offering, etc.).
} 
ventures, focusing in particular on "person," which in our case could be entrepreneurs' motives and attitudes, as well as "environment," would make sense The latter could focus, for example, on firms' "ability to provide or withhold resources and business opportunities" (ibid, p. 42); in our opinion, these environmental antecedents could be, for example, slack resources and unsolicited orders. We draw from rich qualitative evidence documenting the complex nature of internationalization, whereby resources interact with the entrepreneur and context when determining the timing as well as other aspects of the firm's first entry into foreign markets.

Our main contribution is to study how causal antecedents of early internationalization anchored in these three perspectives mix and match to generate the complex causal configurations that in reality motivate firms' internationalization decisions.

\subsection{Entrepreneurial perspective and role of attitudes of entrepreneurs}

The internationalization process is shaped by the attitudes of entrepreneurs because discovery, enactment, and action occur through them. Oviatt and McDougall (2005, p. 542) argue,

Through the lens of their personal characteristics (e.g., years of international business experience) and psychological traits (e.g., risk-taking propensity), entrepreneurs observe and interpret the potential of the opportunity, the potential of communication, transportation, and computer technology to enable internationalization, and the degree of threat from competitors.... These influences on perceptions clarify or cloud the entrepreneur's decision making.

The cognitive psychology literature argues a person's attitude toward an object or class of objects influences his or her response to that object (Ajzen and Fishbein 1977). In other words, a 
correspondence exists between attitude and behavior, as explained by the theory of planned behavior (TPB) (Ajzen 1991; Fishbein and Ajzen 1974). Allport (1935, p. 810), in early theoretical work, defines an attitude as "a mental and neural state of readiness, organized through experience, exerting a directive or dynamic influence upon the individual's response to all objects and situations with which it is related." Eagly and Chaiken (1993, p. 1) define attitude as "a psychological tendency that is expressed by evaluating a particular entity with some degree of favor or disfavor."

Cognitive psychology has gained more popularity in entrepreneurship literature, with a growing number of scholars using the TPB to study the link between entrepreneurial attitudes, such as those toward risk and entrepreneurial behavior (Mitchell et al. 2007; Sommer and Haug 2011). The key arguments of the entrepreneurship literature on attitudes and behavior are consistent with the findings of export scholars. Cavusgil and Nevin (1981), for instance, find "the reluctance of firms to export may be largely attributable to top management's lack of determination to export" (p. 119).

Several attitudinal traits of entrepreneurs have been posited as important antecedents of firm behavior (George 2011; Sommer and Haug 2011). With regard to internationalization, including whether or not it occurs rapidly, the export literature suggests the risk associated with entering new markets is an important determinant (Cavusgil and Naor 1987; Sommer 2010). Attitude toward risk is also one of the key concepts in the entrepreneurship literature (Acedo and Florin 2006; Chaston and Sadler-Smith 2012; Dai et al. 2014). Studies of INVs and BGs often discuss the perceived risk of entering new markets as part of the construct entrepreneurial orientation, finding that it affects different aspects of internationalization, such as its speed, scope, and performance (Javalgi and Todd 2011; Kuivalainen et al. 2007). Anderson, Kreiser, 
Kuratko, Hornsby, and Eshima (2015) suggest the risk-taking sub-dimension of entrepreneurial orientation especially reflects managerial attitudes toward risk. For these reasons, this study includes attitude toward risk as the first entrepreneurial antecedent of early internationalization.

Some studies argue firms perceive exporting to be more profitable than selling in the local market (Ogram 1982). Yet some ambiguity exists because certain studies (e.g., Jaffe et al. 1989) find a positive relationship between export aggressiveness and the perceptions of exportmarket profitability, whereas others (e.g., Bilkey and Tesar 1977) find either no relationship at all or a relationship that varies with the firm's stage of exporting (Ojala 2009). To shed light on this issue, this study includes attitude toward the profitability of export markets as the second entrepreneurial antecedent of early internationalization.

Firms based in small markets may have more incentives to internationalize than those based in large markets, yet not all firms operating in small economies internationalize quickly, and not all firms based in large economies enter new markets slowly (Bell 1995; Czinkota and Ronkainen 1995; Jones et al. 2011). In the context of small entrepreneurial firms, discussing whether the perception of the entrepreneurs rather than reliance on general measures, such as total gross domestic product, deems the market in which they are based as too small for their business is important. However, according to Lyon et al. (2000), management's perceptions typically provide the most precise assessment of conditions within a firm when studying entrepreneurially oriented behavior. For this reason, we include attitude toward the size of the domestic market, and, more specifically, the business opportunities available in such a market, as the third entrepreneurial antecedent of early internationalization. Lu et al. (2010) is, for example, among a number of studies supporting the idea that entrepreneurial internationalization is very 
much opportunity driven. Entrepreneurs' perception of where the opportunities lie guides their behavior.

\subsection{Resource-based antecedents of internationalization}

The literature on international business illustrates numerous resource-based factors that determine behavior and also affect how the competitors behave (Acedo and Galán 2011; Rugman, Verbeke, and Nguyen 2011; Sommer and Haug 2011). In this paper, we are not studying an extensive list of resources, but rather focus on availability of resources. A number of resources could exist, such as technology, but the perception of the entrepreneurial actor in relation to the availability is what clarifies or clouds the decision-making (Oviatt and McDougall 2005). Tuppura et al. (2008) found that resource versatility (i.e., the resources of firms can be used for a number of purposes, such as serving new international customers) is a significant antecedent of first-mover orientation, which eventually leads a firm to follow a BG type of internationalization strategy, which includes early internationalization. The resources a firm can deploy to go abroad affect its internationalization process, including the time it takes to enter its first foreign market. Research has found the availability of unutilized production capacity is a stimulus with a strong impact on the firm's decision to initiate and develop exports (see the meta-analysis of Leonidou et al. 2007). For these reasons, having slack resources such as underutilized capacity serves as an antecedent in our model (Czinkota and Ronkainen 1995; Leonidou 1995; Westhead, Wright, and Ucbasaran 2001). This inclusion is consistent with the idea that entrepreneurs' attitudes result in a certain behavior if they consider such behavior to be feasible under current constraints - in our case, if they think internationalizing at a specific time is feasible (Sommer and Haug 2011). 


\subsection{Market-based antecedents of internationalization}

The MBV posits the idea that external market-based factors often determine firm behavior (e.g., Porter 1979; Kamakura et al. 2012). Scholars explain internationalization as a process firms pursue to achieve a variety of strategic objectives, including capturing a key market before competitors or preventing competitors from acquiring a dominant position in a market (Dimitratos et al. 2004; Johanson and Vahlne 2009; Tuppura et al. 2008). For example, Oviatt and McDougall (2005) include competition as a motivating factor of the speed of internationalization. For this reason, we include, as one of the antecedents of early internationalization, whether firms internationalized as a means to respond to the actions of their competitors (competitors' behavior). A number of studies have investigated competitors' behavior or intensity (from as early as Johanson and Wiedersheim-Paul 1975). In their review of export stimuli, Leonidou et al. (2007) list competition as one of the reactive motives to begin exporting, whereas Cadogan, Cui, and Kwok Yeung Li (2003) found that export-market-oriented behavior is beneficial in situations in which competitive intensity is high.

Other MBV-related antecedents can be a response to potential customers' needs. The entrepreneurship literature illustrates that the discovery and exploitation of business opportunities can be not only a result of a proactive process, but also a reaction to unexpected events (Chandra et al. 2009; Kontinen and Ojala 2011b). Several scholars of internationalization show that receiving unsolicited orders, an event our model examines as an antecedent, can affect the timing and scope of internationalization (Dimitratos et al. 2010; Ellis 2000, 2011; Leonidou 1995), and, all in all, unsolicited export orders account for a substantial share of all foreignmarket entries (Ellis 2011). For example, Ellis (2011) studied Chinese international 
entrepreneurs, and $42 \%$ of the exchange ventures in this study resulted from unsolicited approaches made by potential customers or intermediaries. Leonidou et al. (2007) note in their meta-analysis on export stimuli that during the early export stages, firms are more likely to be influenced by reactive and external factors, which would trigger internationalization, and the receipt of unsolicited orders from foreign customers has in general a very high impact on the commencement of exporting. Having both competitor- and customer-based criteria in the model gives us an idea of how market-based antecedents affect early internationalization.

Figure 1 illustrates the set of antecedents of early internationalization and their exemplary interplay that we examine in this study. Our basic proposition is that each firm can follow its own strategic path to early internationalization—one that best fits its existing resources and capabilities. In many cases, the stimuli might come either from external or internal sources, and sometimes the reason is of a proactive or reactive nature; therefore, export stimulation—a reason for early internationalization—should be seen as the synergistic outcome of a bundle of factors (Leoniou et al. 2007; for similar ideas, see also Chandra, Styles, and Wilkinson 2009; Crick 2009; Ojala 2009). For example, one firm may have internationalized early because the entrepreneur sees exporting as a low-risk activity and profitable, and other aspects are not relevant for the outcome, whereas another entrepreneur in the second firm does not see risk as a relevant issue but internationalizes early because it sees it as profitable and sees the domestic market as too small. We explore these antecedents' interplay next.

$<$ Insert Figure 1 about here> 


\section{EXTENSION OF RESEARCH ON EARLY INTERNATIONALIZERS THROUGH A CONFIGURATIONAL APPROACH}

Attitudes affect behavioral responses to exporting, with one such response being early internationalization. Several studies establish a relationship between these antecedents and early internationalization (e.g., Ellis 2011; Lu et al. 2010; Tuppura et al. 2008). Many of these studies, however, are correlational in nature and symmetrical in their analyses. They posit that the presence of a given antecedent or set of antecedents will lead to the occurrence of the outcome. They argue that the absence of a given antecedent or set of antecedents thought to be associated with the outcome will result in the absence of the outcome. Yet the outcome of early internationalization may arise from a variety of different combinations of antecedents; in other words, different combinations may be sufficient for the outcome. This perspective is consistent with organizational theories of equifinality (Katz and Kahn 1978; Von Bertalanffy 1968) or the notion that, as stated by Katz and Kahn (1978, p. 30), "a system can reach the same final state from differing initial conditions and by a variety of paths.”

The objective in this study is to evaluate and describe alternative paths that may lead to the outcome of "early internationalization;" thus, we report conditions using measures of coverage and consistency to assess the extent to which attitudinal antecedents are sufficient for the outcome to take place.

Correlational methods provide an evaluation of the net effects of independent over dependent variables. As Ragin (2008, p.112) states, "In conventional quantitative research, independent variables are seen as analytically separable causes of the outcome under investigation. Typically, each causal variable is thought to have an autonomous or independent capacity to influence the level, intensity, or probability of the dependent variable." These 
methods are appropriate when sufficiency and necessity occur simultaneously. Other methods, including fsQCA, are more suitable when researching sufficiency alone and when examining phenomena that are complex in nature (Misangyi, Greckhamer, Furnari, Fiss, Crilly, and Aguilera 2017). FsQCA has been used to explain complex causality in several recent studies, notably scholars of national institutions and variety of capitalism, such as Witt and Jackson (2016) and Fortwengel (2017), and scholars of strategy and firm performance, such as Fiss (2007, 2011).

\section{METHODS}

To study sufficiency, equifinality, and asymmetry through alternative configurations of antecedents that are sufficient for the outcome of "early internationalization," we use settheoretic methods, as previously stated, in the form of fsQCA (Ragin and Pennings 2005; Rihoux and Ragin 2009).

In using fsQCA, several methodological steps are needed. First, raw values of the variables are calibrated into fuzzy-set membership scores relying on applicable and substantive empirical knowledge. Second, the patterns of necessary and sufficient conditions are unveiled, and causal complexity is discovered. Third, causal recipes' parameters of fit-consistency and coverage in fsQCA—are assessed regarding the statements of sufficiency and necessity (Ragin and Pennings 2005). Using fsQCA implies relationships among variables are understood as set relations; that is, firms will have variable scores that will represent the degree of membership into some set. The following sections provide further information about the data and research methods used in this study. 


\subsection{Data}

This study focuses on 29 Costa Rican software companies. We first collected information through semi-structured interviews, lasting on average one hour and carried out in the year 2009, with the entrepreneurs who had founded and continued to lead the companies.

During these interviews, a questionnaire was administered, asking the interviewee to provide basic background information about the firm, for example, the number of employees, average sales per year, and year of foundation, and to rank the importance of drivers of internationalization on a 10-point scale (see Table 1 and section 4.5 for more details), building on previous work capturing export antecedents (Cadogan, Kuivalainen, and Sundqvist 2009). One month after we finished this first round of fieldwork, we contacted the entrepreneurs again — via telephone consultations lasting on average 15 minutes— to gather further information about their reasons for entering foreign markets. The temporal break was part of our strategy to verify that the respondents provided the same account or added details to it, as suggested by, for example, Podsakoff, MacKenzie, Lee, and Podsakoff (2003). Finally, through open-ended interviews lasting from 20 minutes to an hour and 15 minutes, depending on the willingness of the entrepreneur to "tell the story," we collected further qualitative empirical evidence about internationalization and the process through which the decisions were made. The last round of interviews followed an instrument guiding the questions, aimed at identifying firm-related, market-related, and entrepreneur-related reasons for searching international business opportunities, as well as enriching our understanding of the internationalization process. $<<$ Insert Table 1 about here>> 
At the time of the data collection, the universe of Costa Rican software producers was estimated to comprise 150 firms (CAMTIC, 2008). We contacted all of the firms on the list obtained from the Costa Rican Chamber of Information and Communication Technology Producers (CAMTIC). After filtering out the firms that were not operational and those that were not willing to participate, we interviewed 40 firms, a response rate of $26 \%$.

Given that we are concerned with small entrepreneurial firms, the interviews were conducted with the founders-those people responsible for firm internationalization (cf., e.g., Dimitratos and Jones 2010). Of the 40 firms studied, we included only those for which we interviewed the founder or co-founder, which gave us firsthand information about the focal phenomenon. We applied this protocol by asking the respondents about their status within the company and corroborating their answers with people familiar with the industry. This process left 33 firms, four of which had not yet exported at the time of the study and were therefore excluded. The final set of cases comprises 29 firms, or $76 \%$ of the Costa Rican software exporters according to CAMTIC and in line with other studies of the sector (Lopez, Kundu, and Ciravegna 2009; Porter and Ketelhöhn 2002).

To limit the effects of country of origin and industry, which some authors argue are important determinants of internationalization (Cadogan et al. 2003; Rugman et al. 2011), this study looks only at Costa Rican business-to-business (B2B) firms exporting software packages and related services, such as maintaining and updating software they installed for a client. All firms employ fewer than 100 people, are based in Costa Rica, and have yearly average sales of less than US\$5 million. The entrepreneurs share several characteristics: they are between 30 and 50 years old, they are from Costa Rica, and they have a background in electronic engineering or computing. The highly homogenous characteristics of our sample are consistent with the key 
features of the Costa Rican software and electronics industry (Villalobos and Monge-González 2011). Such homogeneity in personal characteristics allowed us to control for the effects of entrepreneurial background on internationalization and firm size, and focus instead on other antecedents (Oviatt and McDougall 2005).

We chose to examine a sample of firms from Costa Rica because the country hosts a very dynamic high-technology industry and is a small, open economy that allows for examination of entrepreneurial antecedents for internationalization for firms based in small domestic markets (Porter and Ketelhöhn 2002; World Bank Group 2006).

\subsection{Antecedents}

This study focuses on three groups of antecedents for early internationalization: first, entrepreneurial, attitudinal antecedents related to risk and profitability of internationalizing, and the limited size of the domestic market; second, resource-based antecedents (here, existence of underutilized capacity), and third, market-based antecedents related to reception of unsolicited orders, and the behavior of competitors. See Table 2 for descriptive statistics and correlations for these variables.

\subsection{Calibration}

In fsQCA, data are calibrated into set membership values that range between 0 and 1 . Zero implies full non-membership, and 1 implies full membership into the set. Unlike crisp sets (in which membership is 0 or 1 ), fuzzy sets contain values that are not necessarily at the extremes of the continuum. For this reason, at least a third value is needed to express a crossover point that defines both the point of maximum ambiguity and a boundary for being in or out of a set (Ragin 2008). Thus, a link between antecedent and outcome is established if consistent 
membership in the outcome is linked to consistent membership in a combination of antecedents (Ragin and Pennings 2005).

\subsection{Calibration of the outcome}

The outcome of interest is the timing of internationalization, which is normally measured as age at first entry or, in other words, the time elapsed between firm inception and first export (Acedo and Jones 2007). Although the notion of early internationalization is straightforward, its operationalization varies. Knight and Cavusgil (2005, p. 16) define BG firms as "companies that, from or near founding, obtain a substantial portion of total revenue from sales in international markets." This definition is in line with that of INVs (specifically, Oviatt and McDougall 1994). Knight, Madsen, and Servais (2004) define early internationalizers as firms that start to export within three years of their founding; Bloodgood et al. (1996) use less than five years; and Zahra, Ireland, and Hitt (2000) and Shrader et al. (2000) use six years or less. We could argue these variations in operationalization reflect an inherent ambiguity in the concept-its fuzziness. Thus, using fuzzy sets may prove particularly fruitful. We calibrated membership in the earlyexporters group by setting zero years as the full-membership score (i.e., firms that exported the year of their inception) and 12 years as the cutoff for the full-non-membership score. The point of maximum ambiguity, that is, the point that defines the boundary or qualitative separation between being "in" or "out" of the set of early internationalizers, was fixed at six years (following Zahra et al. 2000 and Shrader et al. 2000). We defined continuous set memberships using the log-odds method outlined by Ragin (2008). Notice that firms are not being coded into one category or another here, such as fast internationalizers or slow internationalizers, as one would do if using crisp sets. Rather, we establish the degree of membership into the set of fast exporters. Fuzzy sets allow this degree of membership assessment. In a sense, fuzzy sets allow 
the establishment of how far a firm is from one or the other extreme; therefore, fuzzy-set principles can be used to explore the questions of interest (Rihoux and Ragin 2009).

\subsection{Calibration of antecedents}

The study includes six antecedents: (1) the entrepreneurs' attitude toward risk, (2) their attitude toward profitability, (3) their attitude toward the limitations of their domestic market, (4) whether the firm has underutilized capacity, (5) whether it has reacted to competitors' behavior, or (6) whether it has received unsolicited orders. We asked the interviewees to assess on 10-point scales the extent to which they agreed with the following statements representing the antecedents $(1$ = strongly disagree, 10 = strongly agree $)$ : (a) Exporting is risky; (b) Operating in foreign markets is profitable; (c) The domestic market is too small; (d) I started to export because my competitors did the same; (e) At the time of my first export, I had underutilized capacity to leverage to serve more clients; and (f) I first exported because I received unsolicited orders.

We calibrated membership into the corresponding fuzzy sets by taking the highest possible score as the anchor for full membership, the smallest possible score as the anchor for full non-membership, and the scale's midpoint as the qualitative boundary that separates "in" from "out" (Ragin 2008). The questions were reversed for two attitudinal antecedents, in the sense that a high score meant the entrepreneurs perceived a high risk involved in exporting or that exporting was not profitable for the organization. Hence, in these last two cases, a score of 1 would mean full membership into the set of entrepreneurs that perceive exporting as a high-risk activity, and similarly for profitability.

\section{RESULTS}


To assess whether any of the antecedents of early internationalization heretofore discussed could be considered necessary for the outcome to occur, we checked if an antecedent, or a combination of antecedents, was present in all cases, which, consistent with fsQCA methods, shared the same outcome, namely, early internationalization (Ragin 2008). Following Ragin's (2006) suggestions, we used consistency measures to investigate the degree to which cases adhered to the specified rule to verify whether the set membership value of the outcome was smaller than the set membership value of the antecedent. The consistency score Ragin (2006) suggests measures how well cases follow this rule, by determining how many cases do not meet the rule and by how much they miss it. A consistency score of 1 means the antecedent, or combination of antecedents, meets the rules for all cases. A consistency score that exceeds 0.90 indicates the antecedent or combination of antecedents is necessary. The antecedents (see Table 2) were tested for necessity, and the results appear in Table 3. Equations for determining consistency scores are provided in Appendix 1.

$<<$ Insert Table 2 about here>>

Table 3 reports the results of the fuzzy-set analysis of early internationalization. This analysis was performed using the fsQCA software package (Ragin 2008). For simplicity, the names of the antecedents of interest are abridged as follows: unsolicited order $=\mathrm{O}$; exports by competitor $=\mathrm{C}$; small domestic market $=\mathrm{M}$; underutilized capacity $=\mathrm{U}$; export markets risky $=$ $\mathrm{R}$; and export markets not profitable $=\mathrm{P}$.

$<<$ Insert Table 3 about here>>

The only consistent antecedent in Table 3 that exceeds the conventional 0.9 threshold is the small domestic market. This antecedent can be considered necessary in the set of cases under scrutiny. We also performed a test for substitutable necessary conditions in fsQCA (this test was 
meant to investigate if two causal conditions [or antecedents] that are operated by a logical OR are a necessary condition for the outcome). The antecedent $\mathrm{R}+\mathrm{P}$ ("There is too much risk in exporting" OR "Exporting is not sufficiently profitable for the organization") is inconsistent with the outcome. The OR operation on both antecedents was negated; however, it is consistent with the outcome, as shown in the last row of Table 3. This result is consistent with the expectation that the outcome, early internationalization, would be associated with exporting either not being considered a risky endeavor or not being unprofitable. That the small domestic market is a necessary antecedent for the firms represented in the data set does not come as a surprise, because this antecedent has substantive support in the literature (Bell 1995; Czinkota and Ronkainen 1995). Given that, we explored what other antecedents could be linked to the outcome "early internationalization," by examining whether any combinations of antecedents were sufficient for the outcome to occur (Ragin 2008).

We chose a consistency cutoff value of 0.837 . This value is larger than the recommended rule of the cutoff value not being smaller than 0.75 (Ragin, 2008). Given the relatively small number of cases, we use a frequency cutoff value of 1.

Our next step was to determine if the configurations were a subset of the membership in the outcome. The procedure revealed the following:

\section{EARLY INTERNATIONALIZATION $\geq\left(\sim \mathrm{U}^{*} \mathrm{M}^{*} \sim \mathrm{C}^{*} \sim \mathrm{R} * \sim \mathrm{P}\right)+\left(\sim \mathrm{O}^{*} \sim \mathrm{U}^{*} \mathrm{M}^{*} \sim \mathrm{C}^{*} \sim \mathrm{P}\right)+$ $(\mathrm{O} * \mathrm{U} * \mathrm{M} * \mathrm{C} * \mathrm{R} * \mathrm{P})$}

The equation, which is the summary of our findings, shows that three paths, or configurations of antecedents, lead to the outcome, namely, early internationalization. Table 4 
presents coverage and consistency of the three configurations. In this case, all the combinations of antecedents are consistent subsets of the outcome. The solution coverage is equal to 0.68 , and the solution consistency is equal to 0.84 . As Ragin (2006) explains, consistency evaluates the degree to which the cases that share a particular combination of antecedents also display the outcome (early internationalization). Coverage evaluates to what extent the combination of antecedents accounts for instances of the outcome. Therefore, coverage is a measure of the importance or relevance of the solution. Appendix 2 shows how coverage and consistency are determined when assessing sufficiency.

Table 4 partitions the solution coverage to assess the relative importance of the different causal combinations. Raw coverage indicates the fraction of instances of the outcome that are embraced by the configurations. The raw coverage of the three configurations identified in the complex solution are 53\%, 52\%, and $11 \%$ for Configurations I, II, and III, respectively. Coverage can be partitioned to assess the coverage that is unique to one particular configuration. For the three configurations, unique coverages are $14 \%, 11 \%$, and $2 \%$, respectively; the difference between the two is due to overlapping. The three configurations are also presented in a more descriptive form in Table 5.

$<<$ Insert Tables 4 and 5 about here>>

Figure 2 is a Venn diagram of the results. The largest circle in the diagram represents the set of cases that show membership in the outcome, and the smaller circles inside represent the cases that exhibit membership in a particular combination of antecedents, also in the outcome. The diagram approximately illustrates which coverage of the outcome is uniquely due to any one 
of the causal combinations, helping to describe the set of theoretical relationships between causes and outcome. Measures of coverage and consistency are descriptive tools and are not intended as inferential tools. The Venn diagram implies the existence of interesting, or at least different, typologies for early internationalization. The diagram also hints at firms leaning more toward one combination of these antecedents than another (or, said differently, more toward one of the corners of the $2^{\mathrm{k}}$ space created by the $\mathrm{k}$ antecedents); it also signals the number of consistent combinations is limited.

$<<$ Insert Figure 2 about here >>

\section{CONFIGURATIONS}

The small-market motivation for exporting quickly is present in all three configurations, even though they are combined with different antecedents. A small home market in the software industry often means exporting is critical to a firm's long-term survival and growth, and in some cases, firms may internationalize even before they have had any domestic customers (Bell 1995). Market for software is global, but some markets are evidently bigger than others; for example, the US market accounts for 32.6\% of the global market value (MarketLine, 2017). Additionally, software has other features that may support early internationalization when firms are based in small markets. First, it is a knowledge-intensive industry, which entails entrepreneurs may have superior access to knowledge about markets and opportunities, but the industry and product characteristics mean product life cycles are short and the research and development costs are high (Bell et al. 1995; Cusumano 2004). Second, it is an intangible industry, which means internationalizing entails fewer barriers, ranging from regulations to tariffs and transport costs. 
The first configuration shows some firms internationalize quickly, motivated primarily by the limitations of a small domestic market together with their attitudes toward internationalizing, which they consider to be neither risky nor unprofitable (see Tables 4 and 5). The firms of Configuration I all specialize in B2B customized software initially targeted for Costa Rican clients, which they then adapted for foreign markets. These firms have no excess capacity and do not respond to competitors' behavior; in other words, their internationalization is not reactive, in that it is not a reaction to either having unused resources or the actions of competing firms. Here the entrepreneur has a clear attitudinal predisposition toward internationalization, not contemplating its riskiness related to, for example, liability of foreignness or the fact that foreign markets might not be profitable. The entrepreneurs of the first configuration were sure of their decision to internationalize, though they admitted it was not a predetermined plan or path when they founded the firm, which would be the case in Configuration II, and they did ponder whether it would be risky or profitable.

One of them, for example, stated,

Exporting reduced our dependency on the domestic market, so in a sense it was an attempt to do what was less risky. Imagine you depend on a market of four million people, with our average income per head...that must be equivalent to a neighborhood in New York..., would you consider that to be a safe strategy? I think that entering foreign markets was no more risky than starting this business...but when I started the firm that was not in my mind, it is something I came to think after we were up and running, with some local clients and a team... when I decided we needed to export, I began mobilizing all the contacts I had abroad...first to get information, then to get introduced to potential 
clients...I had really no idea how to go about it, you know this was not a multinational, just a small firm, but at the end it worked.

Interestingly, the accounts of these entrepreneurs do not mention factors related to the available firm capacity, suggesting on the contrary that they were willing to retreat from the domestic market to focus on exports. For example, one said, "We really had to get out there, so I hired three foreign sales managers and began sending them everywhere...it cost me a lot of money, and after a while I learned I needed to be more focused on specific markets and clients, but we did manage to find foreign clients very quickly."

The second configuration of antecedents is similar, but in this case, attitude about the risk of exporting is not relevant; in other words, whether entrepreneurs consider exporting to be risky does not influence their decision to internationalize soon after inception (see Tables 4 and 5). These firms are moved primarily by the limitations of the small market and the perception of exporting not being unprofitable, but risk does not seem to play a role. This finding is surprising because internationalizing quickly is often associated with risk-prone behavior (Shrader et al. 2000). This perspective can be interpreted as a calculated decision to internationalize quicklyone in which the firm seeks foreign markets based on the entrepreneur's attitude toward the profitability of internationalizing. As in the first configuration, these firms do not have underutilized capacity. One entrepreneur explained his decision with this statement: "With the type of product we had, from the start we knew we had to target international markets. It was not about whether or not it would be risky...it had to be done....had I thought we could not make profits in international markets I would have not started this firm or developed a different product." Another said, "When we launched this, we had in mind a few strategic foreign 
clients...we were not interested in the local firms...we were focusing on what was happening in the US, at the 'heart' of the technological change, not here."

In the third configuration, entrepreneurs internationalize quickly when they receive unsolicited orders, in spite of perceiving export markets as both risky and unprofitable (see Tables 4 and 5). As in the other two configurations, they consider their domestic market to be too small, but in this case, they do have underutilized capacity. This causal path to the outcome shows a much more passive or reactive configuration of antecedents in which entrepreneurs, despite perceiving exporting as risky and unprofitable, do enter foreign markets early but somewhat accidentally; they receive an unexpected order and have the capacity to fulfill it, which is consistent with the argument that serendipity may play a role in internationalization decisions (Ellis 2011; Kontinen and Ojala 2011b). For example, one entrepreneur said, Exporting? I had never thought of that. You know, I had this small business, I was happy to be able to make a living with a few contracts here... I knew I could never grow the business much because it is a small market, but I was somewhat ok with it. You could say I was not ambitious enough...then one day, we receive this call, and one thing leads to the other, before I know it we have the first foreign client... of course, it helped that we had just finished a large project so we had the people to work on it (the foreign sale). Another entrepreneur said, Here, I know the market very well. Abroad, not at all. The risk of getting into something I do not fully understand...for that reason I was not ready to export. I was scared of the idea, scared that it might burn our resources, which were scarce at the time. Of course I knew that being only a domestic firm there were limits to how much we could sell, but I thought it is better to stay small than to put everything we worked for at risk. At the same 
time, I am an entrepreneur...the opportunity came unexpected and I took it...yes, I did think it was risky, but as an entrepreneur you always take risks. I would have not sacrificed a local client for an unknown foreign client. But we had space for one extra contract at the time, so I decided to give it a shot and see what happens.

We concluded the analysis by examining plausible configurations that do not lead to early internationalization. A fuzzy-set analysis modeling not early internationalization, using the same set of antecedents, revealed results that were not particularly illuminating. Only one instance exhibited a consistent membership in one corner of the vector space of the said antecedents that led to the outcome "not early internationalization." The firms that did not internationalize early are led by entrepreneurs that consider exports to be risky and not necessarily profitable, in spite of the small domestic market, such as those of Configuration III. Unlike Configuration III, however, these firms did not receive unsolicited orders, or, in one case, received an unsolicited order when they had no spare capacity to attend it.

\section{CONCLUSIONS AND DISCUSSION}

This study uncovers three configurations of antecedents for early internationalization, all of which include perceiving the domestic market as too small. The three configurations present subtle but important differences in the causal paths that lead to early internationalization and show that the combination of causal factors, derived from the MBV, RBV, and entrepreneurial perspective, is what really explains when firms first internationalize, as opposed to each of the individual antecedents by themselves.

The first reveals an entrepreneur who actively seeks to minimize the limitations imposed by a small domestic market by venturing abroad, considering internationalization to be neither 
too risky nor unprofitable, which is consistent with the literature on international entrepreneurship (Andersson and Wictor 2003; Dimitratos et al. 2010; Javalgi and Todd 2011; Jones et al. 2011; Oviatt and McDougall 2005; Shepherd and De Tienne 2005; Zahra et al. 1997). Zahra et al. (1997) studied the role of the domestic market as a driver of internationalization and international performance. They concluded that dynamism in the home market might encourage the ventures to seek additional sources of revenue from overseas. The domestic-market environment and its dynamism, hostility, and heterogeneity can all affect international performance (Zahra et al. 1997). Many of the above-mentioned studies mentioned entrepreneurial mindset, or global mindset, vision, and dimensions of entrepreneurial orientation, such as innovativeness and risk-taking, as drivers of internationalization (e.g., Andersson and Wictor 2003). Furthermore, Javalgi and Todd (2011) found that entrepreneurial orientation leads to a higher degree of internationalization, and a number of studies have reached similar findings related to attitudes toward risk (see, e.g., the review of Jones et al. 2011). These firms, unlike those of Configuration II, specialized in non-niche products and services such as humanresource-management software programs. The entrepreneurs developed the business with local and regional markets in mind, as opposed to planning to target only a few non-local clients from the start, as the firms of Configuration II. However, unlike the entrepreneurs of Configuration III, the entrepreneurs of Configuration I see internationalization as an attractive perspective and pursue it actively. The entrepreneurs took action early to pursue internationalization to compensate for the small size of the domestic market, using their time, effort, networks, and ideas. The entrepreneurs described their efforts as focusing on the need to "find new markets," “diversify into new territories," and "enter new countries." They pursued internationalization by attending trade fairs and other events and by building and using personal contacts with 
professionals operating in markets in which they were interested, which is consistent with Coviello (2006). All the entrepreneurs of the first configuration emphasized their personal involvement in the internationalization process, as opposed to providing a description focused on the business model and the firm features, as entrepreneurs belonging to the second configuration, or focusing on external factors, namely, unsolicited orders, as drivers for internationalization, which was prevalent among entrepreneurs belonging to the third configuration.

In Configuration II the domestic market is too small and foreign markets are seen as not unprofitable. However, in this configuration, unlike in Configuration I, risk does not appear to be a relevant factor. The firms in Configuration II did not receive unsolicited orders, whereas this factor was not relevant for the outcome in Configuration I. The fact that risk is not a relevant factor for Configuration II, whereas it is in both Configuration I and Configuration III, points to a more strategic approach to internationalization, whereby factors other than the risk perception of the entrepreneur determine early internationalization. This configuration resembles the behavior of larger firms (multinational corporations) that are not affected by the same level of resource constraints and the risks associated with them as INVs and BGs (Johanson and Vahlne 1990; Oviatt and McDougall 1994; Rugman et al. 2011). This notion is interesting because many recent studies have emphasized the role of effectuation in decision-making, in contrast to the more rational or causal planning and decision-making (e.g., Nummela et al. 2014; Kalinic et al. 2014). Our study shows some companies clearly follow a more or less rational approach, which, combined with the small domestic-market causal antecedent, leads to early internationalization, regardless of whether they do or do not have unused capacity.

The low importance of risk found in Configuration II can be explained by the fact that internationalization was always part of the strategic plan for these entrepreneurs, which reduces 
the role of risk perception when deciding whether to move early or later. An example of such a firm is one specializing in a software that automates the programming operations needed when moving programs across different operating systems. The entrepreneur always planned to sell to foreign buyers and knew his firm could not survive in its small domestic market. The firms of Configuration II have few large clients in one or two foreign markets, which account for the majority of their sales. Notably, two of these firms opened a subsidiary abroad to improve their service to one of their key foreign clients.

The third configuration shows a much more reactive type of entrepreneur: one who sees risk and unprofitability in export markets and domestic-market limitations, but for whom the reception of unsolicited orders and the existence of underutilized capacity are part of the antecedents for becoming early internationalizers. This configuration is somewhat consistent with the idea of serendipity affecting international entrepreneurship (Jones and Coviello 2005; Kontinen and Ojala 2011b). Yet it combines elements of serendipity with specific entrepreneurial attitudinal antecedents, whereby the entrepreneur considers internationalizing to be risky and not profitable but is aware of the limitations of the domestic market and thus seizes the international business opportunity (Crick and Spence 2005; Ellis 2011; Jones and Coviello 2005). The firms of Configuration III developed products specifically for local clients, such as local retailers. Given the similarities of Costa Rica to other markets in the region, such as El Salvador or Guatemala, these products were also suitable for some foreign clients, which contacted them from abroad and sealed their first exports. Some of the firms in this group may also consider following an incremental internationalization path (e.g., Johanson and Vahlne 2009), and overcome the obstacles over time through learning and becoming part of the local networks, which would lower the risks involved in internationalization. One of the entrepreneurs 
said, "After that first foreign sale, we understood that it could be done, we could try having a few other foreign clients...it was risky but it could open new opportunities for growth, and we were always aware of how small Costa Rica is." For these firms, internationalizing was a learning process, unplanned, but changed the opportunity-searching mechanisms for the entrepreneurs, who subsequently began to include foreign markets in their business plans, influencing the way they conceptualized and marketed their products. Another entrepreneur said, "I still consider it risky, but now I do think about foreign markets....at the time (of the first export) it was something completely outside of my preoccupations...now I think about whether something I am working on could be suitable for clients abroad or not."

The firms of Configuration III internationalized mainly, though not exclusively, toward regional markets, the origin of unsolicited orders. Similar to the firms of Configuration II, they entered a small number of foreign markets because of specific clients as opposed to openly pursuing new opportunities in unexplored new markets.

\subsection{Theoretical Implications}

This study illustrates that entrepreneurial firms can be early internationalizers for different combinations of reasons, as argued by scholars who study exporters (e.g., Leonidou et al. 2007). This study responds to calls for the use of multiple theoretical frameworks and innovative data analytical strategies such as fsQCA in international business (Welch et al. 2011). Our results are helpful in framing the ideal sets of factors or antecedents. For example, first consider the findings of Fan and Phan (2007) who, in their study focusing on intra-European airlines, suggested the size of the firm's domestic market and its production capacity, as well as economic forces, affect a new venture's decision to internationalize at its founding. Second, 
consider Armario et al. (2008), who state their major contribution was to establish market orientation as a distinctive competence supporting firms' activities in foreign markets. Third, several studies look at factors leading to different types of timing and presence in international markets (e.g., Kuivalainen et al. 2007; Tuppura et al. 2008; Baum et al. 2011). Kuivalainen et al. (2007), for example, focus on international entrepreneurial orientation; Baum et al. (2011) look at antecedents such as product differentiation and growth orientation; and Tuppura et al. (2008) examine resource versatility and international growth orientation. Whether different paths could lead to a similar outcome, namely, early internationalization, is much less known or at least less theorized. We believe that the complex causality we have uncovered helps to refine the understanding of the process of internationalization. Multiple, complementary theoretical viewpoints would be helpful to frame the reality, and in this effort, fsQCA can be a helpful method (cf. also Misangyi et al. 2017). Thus, we encourage scholars to use fsQCA in internationalization-process studies in the future.

In our study, we used antecedents from the three well-known literature streams (international entrepreneurship literature, RBV, and MBV) and showed three possible configurations linked to the interaction of the antecedent "small market" with other antecedents, namely, attitude toward risk and profits, under-used resources, and unsolicited orders. Our categorizations can provide a platform for theoretically grounded typologies about how different types of firms may pursue international opportunities early in their life cycles.

We should also emphasize the different types of configurations and their possible link to different strategic layers in the industry. The focal industry, software, is inherently global but also contains different strata because some standardized internet- or cloud-based software can be very global, whereas some tailor-made B2B software can be very local. In his seminal study on 
small-software-firm internationalization, Bell (1995) found that key factors affecting market selection were client followership, sectoral targeting (i.e., niche strategy), and computer-industry trends (e.g., concentration of the markets and growth rates in different markets). Ojala and Tyrväinen (2007) found that software-market size and geographic distance of the market could explain $70 \%$ of country choices of Finnish software SMEs. The market size explains much of the US market entry of many focal Costa Rican firms belonging to Configuration II, where the decision-making followed a more or less rational strategic planning trajectory. In Configuration II, the reason for early internationalization may be more reactive and based on serendipity, hence the more regional focus in internationalization. Many of the firms had actually very narrow regional focus (i.e., Central America).

\subsection{Managerial Implications}

Our findings are relevant for entrepreneurs and managers because they illustrate that small firms can become early internationalizers via different paths, as opposed to through a unique and possibly difficult-to-imitate trajectory. The size of the domestic market seems to act as a commonly understood driver, though it triggers entrepreneurs to internationalize only when it combines with other factors. The one common denominator is the risk-return trade of the entrepreneur, which affects the resource allocation, scope of international expansion, and performance. Different pools of resources may eventually provide the basis for the same outcome, namely, early internationalization. Understanding the relevant resources, studying the decision-maker characteristics and market-based factors, and comparing these with the found configurations can provide managers and entrepreneurs a tool kit for moving the firm forward. The presented configurations can provide benchmarks and heuristic value in general in decision- 
making on (early) internationalization. The results are particularly important for firms that focus on niche products and services, which need to quickly sell in multiple markets in order for these firms to survive and eventually grow. In their planning, they could relate to and benchmark Configuration II, for example. Another implication of our study is that the entrepreneurs who plan internationalization as part of their broader strategy factor in risk from an earlier stage, and hence may not "find" internationalization to be risky, because not internationalizing was never a real possibility, given that they focused on niche products (Configuration II). On the contrary, attitude toward risk is an important causal antecedent of internationalization for the entrepreneurs who initially focus on the local market, as do those of Configuration I and III, whereby only those who find international markets to be neither unprofitable nor risky (Configuration I) may pursue them, whereas those who do find them risky and possibly unprofitable (Configuration III) will do so but only in reaction to specific circumstances, that is, having capacity and responding to an unsolicited order. The configurations are also more broadly relevant for firms based in small economies, which face the limitations of operating in small domestic markets.

\subsection{Limitations and further research}

The configurations found in this study can provide a basis for a number of new studies. Reuber et al. (2017, p. 418) suggested that whether different paths can lead to similar outcomes (i.e., early internationalization in our study) is under-theorized in the international entrepreneurship literature, and that scholars should "develop theoretically grounded typologies about how diverse firms may pursue international opportunities in different - but effective ways." The configurations presented here could be used as categories to build typologies that can help in the building of integrative theories that cover multiple causal relationships between 
structures, strategies, and contexts (cf. Child 1972; Fiss 2011). Second, we believe the role of decision-making in the configurations could also be studied further. Our findings provide evidence on more rational and less rational decision-making on early internationalization, showing that not all BGs and INVs are the same.

We acknowledge that our study was exploratory due to its limitations. For instance, the large overlap found in the configurations of antecedents suggests additional variables such as networks (Coviello and Munro 1997; Johanson and Vahlne 2009), strategic orientation, and industry life cycle (Cavusgil and Knight 2015) might be needed to obtain cleaner typologies. Consequently, in the future, even more holistic studies of different stimuli for early internationalization should be taken into consideration. Furthermore, our measures, being single variables, may be prone to measurement error. One possible avenue for further research would be to gather data related to entrepreneurial attitudinal variables based on multi-item scales to add to the validity of our results.

The Costa Rican context has certain unique cultural characteristics. However, because the software industry is a high-tech industry and has a large international ethos, we believe our results are rather generalizable_ - at least in the context of small, open, developing economies. Clearly, being based in a small economy contributes to explaining the importance of the small size of the domestic market as a driver for early internationalization. However, this result is consistent with previous research (Phan and Fan, 2007; Ojala and Tyrväinen, 2007). Further, as mentioned above, naturally even within the software industry some segments have more opportunities, whereas some firms may only have potential customers abroad - and all in all the idea of the market size might be perceptional. Future studies should explore further the role of market-size perceptions. 
Natural effects may stem from contextual factors in our research, for example, in relation to target-market selection (cf. Ojala and Tyrväinen 2007 for Finnish software firms). Hence, another possible avenue is to replicate the study by examining low-tech firms, larger companies, and firms based in large economies and economies in different levels of development, so as to develop a more refined set of configurations to explain why some firms internationalize quickly and others take longer. Finally, studying the performance consequences of the configurations would be of importance. Even though a number of paths lead to early internationalization, we lack information on the outcomes of early internationalization. Some studies explain the role of individual factors (see, e.g., the review of Jones et al. 2011), but the nature of the method used here, fsQCA, can provide new insights on this matter. We hope our study can provide a platform for these types of endeavors. 


\section{REFERENCES}

Acedo, F. J., \& Florin, J. (2006). An entrepreneurial cognition perspective on the internationalization of SMEs. Journal of International Entrepreneurship, 4(1), 49-67.

Acedo, F. J., \& Galán, J. L. (2011). Export stimuli revisited: The influence of the characteristics of managerial decision makers on international behaviour. International Small Business Journal, 29(6), 648-670.

Acedo, F. J., \& Jones, M. V. (2007). Speed of internationalization and entrepreneurial cognition: Insights and a comparison between international new ventures, exporters and domestic firms. Journal of World Business, 42(3), 236-252.

Ajzen, I. (1991). The theory of planned behavior. Organizational Behavior and Human Decision Processes, 50(2), 179-211.

Ajzen, I., \& Fishbein, M. (1977). Attitude-behavior relations: A theoretical analysis and review of empirical research. Psychological Bulletin, 84(5), 888.

Allport, G. W. (1935), Attitudes, in C. Murchison (Ed.), Handbook of Social Psychology, Clark University Press, Worcester, 798-844. 
Anderson, B. S., Kreiser, P. M., Kuratko, D. F., Hornsby, J. S., \& Eshima, Y. (2015).

Reconceptualizing entrepreneurial orientation. Strategic Management Journal, 36(10), 15791596.

Andersson, S. (2000). The internationalization of the firm from an entrepreneurial perspective. International Studies of Management \& Organization, 63-92.

Andersson, S., \& Wictor, I. (2003). Innovative internationalisation in new firms: born globalsthe Swedish case. Journal of International Entrepreneurship, 1(3), 249-275.

Armario, J. M., Ruiz, D. M., \& Armario, E. M. (2008). Market orientation and internationalization in small and medium-sized enterprises. Journal of Small Business Management, 46(4), 485-511.

Autio, E., Sapienza, H. J., \& Almeida, J. G. (2000). Effects of age at entry, knowledge intensity, and imitability on international growth. Academy of Management Journal, 43(5), 909-924.

Barney, J. (1991). Firm resources and sustained competitive advantage. Journal of management, 17(1), 99-120.

Baronchelli, G., \& Cassia, F. (2014). Exploring the antecedents of born-global companies' international development. International Entrepreneurship and Management Journal, 10(1), 6779. 
Baum, M., Schwens, C., \& Kabst, R. (2011). A typology of international new ventures: Empirical evidence from high-technology industries. Journal of Small Business Management, 49(3), 305-330.

Bell, J. (1995). The internationalization of small computer software firms: A further challenge to "stage" theories. European Journal of Marketing, 29(8), 60-75.

Bilkey, W. J., \& Tesar, G. (1977). The export behavior of smaller-sized Wisconsin manufacturing firms. Journal of International Business Studies, 93-98.

Bloodgood, J. M., Sapienza, H. J., \& Almeida, J. G. (1996). The internationalization of new high-potential US ventures: Antecedents and outcomes. Entrepreneurship Theory and Practice, 20, 61-76.

Cadogan, J. W., Cui, C. C., \& Kwok Yeung Li, E. (2003). Export market-oriented behavior and export performance: The moderating roles of competitive intensity and technological turbulence. International Marketing Review, 20(5), 493-513.

Cadogan, J. W., Kuivalainen, O., \& Sundqvist, S. (2009). Export market-oriented behavior and export performance: quadratic and moderating effects under differing degrees of market dynamism and internationalization. Journal of International Marketing, 17(4), 71-89. 
CAMTIC (2008). Database of the Costa Rican Information and Telecommunication

Technologies Producers. CAMTIC internal document. San José, Costa Rica: Chamber of Information and Communication Technologies (CAMTIC).

Casillas, J. C., \& Acedo, F. J. (2013). Speed in the internationalization process of the firm. International Journal of Management Reviews, 15(1), 15-29.

Cavusgil, S. T., \& Knight, G. (2015). The born global firm: An entrepreneurial and capabilities perspective on early and rapid internationalization. Journal of International Business Studies, $46(1), 3-16$.

Cavusgil, S. T., \& Naor, J. (1987). Firm and management characteristics as discriminators of export marketing activity. Journal of Business Research, 15(3), 221-235.

Cavusgil, S. T., \& Nevin, J. R. (1981). Internal determinants of export marketing behavior: An empirical investigation. Journal of Marketing Research, 114-119.

Chandra, Y., Styles, C., \& Wilkinson, I. (2009). The recognition of first time international entrepreneurial opportunities: Evidence from firms in knowledge-based industries. International Marketing Review, 26(1), 30-61.

Chaston, I., \& Sadler-Smith, E. (2012). Entrepreneurial cognition, entrepreneurial orientation and firm capability in the creative industries. British Journal of Management, 23(3), 415-432. 
Child, J., (1972). Organization structure and strategies of control: A replication of the Aston study. Administrative Science Quarterly, 17, 163-177.

Coviello, N., \& Munro, H. (1997). Network relationships and the internationalisation process of small software firms. International Business Review, 6(4), 361-386.

Crick, D. (2009). The internationalisation of born global and international new venture SMEs. International Marketing Review, 26(4/5), 453-476.

Crick, D., \& Spence, M. (2005). The internationalisation of 'high performing'UK high-tech SMEs: a study of planned and unplanned strategies. International Business Review, 14(2), 167185.

Cusumano, M. (2004). The Business of Software - What every Manager, Programmer, and Entrepreneur Must Know to Thrive and Survive in Good Times and Bad. Free Press, New York, NY.

Czinkota, M. and I. Ronkainen (1995), International Marketing. Dryden Press, Sydney.

Dai, L., Maksimov, V., Gilbert, B. A., \& Fernhaber, S. A. (2014). Entrepreneurial orientation and international scope: The differential roles of innovativeness, proactiveness, and risk-taking. Journal of Business Venturing, 29(4), 511-524. 
Dimitratos, P. and Jones, M. V. (2010), Resources, Efficiency and Globalization, Palgrave Macmillan, London.

Dimitratos, P., Lioukas, S., \& Carter, S. (2004). The relationship between entrepreneurship and international performance: the importance of domestic environment. International Business Review, 13(1), 19-41.

Dimitratos, P., Plakoyiannaki, E., Pitsoulaki, A., \& Tüselmann, H. J. (2010). The global smaller firm in international entrepreneurship. International Business Review, 19(6), 589-606.

Eagly, A. H. and S. Chaiken (1993), The Psychology of Attitudes. Harcourt Brace/Jovanovich College Publishers, Orlando, FL.

Eisenhardt, K. M., \& Graebner, M. E. (2007). Theory building from cases: Opportunities and challenges. Academy of management journal, 50(1), 25-32.

Ellis, P. (2000). Social ties and foreign market entry. Journal of International Business Studies, 31(3), 443-469.

Ellis, P. D. (2011). Social ties and international entrepreneurship: Opportunities and constraints affecting firm internationalization. Journal of International Business Studies, 42(1), 99-127.

Fan, T., \& Phan, P. (2007). International new ventures: revisiting the influences behind the 'born-global' firm. Journal of International Business Studies, 38(7), 1113-1131. 
Fishbein, M., \& Ajzen, I. (1974). Attitudes towards objects as predictors of single and multiple behavioral criteria. Psychological review, 81(1), 59.

Fiss, P. C. (2007). A set-theoretic approach to organizational configurations. Academy of Management Review, 32(4), 1180-1198.

Fiss, P.C. (2011). Building better causal theories: A fuzzy set approach to typologies in organization research. Academy of Management Journal, 54(2), 393-420.

Fortwengel, J. (2017): Understanding when MNCs can overcome institutional distance: A research agenda. Management International Review, forthcoming.

George, B. A. (2011). Entrepreneurial orientation: a theoretical and empirical examination of the consequences of differing construct representations. Journal of Management Studies, 48(6), 1291-1313.

Gil-Pechuan, I., Exposito-Langa, M., \& Tomas-Miquel, J. V. (2013). International entrepreneurship in SMEs: a study of influencing factors in the textile industry. International Entrepreneurship and Management Journal, 9(1), 45-57.

Harms, R., Kraus, S., \& Schwarz, E. (2009). The suitability of the configuration approach in entrepreneurship research. Entrepreneurship and Regional Development, 21(1), 25-49. 
Jaffe, E. D., Nebenzahl, I. D., \& Pasternak, H. (1989). The export behavior of small and medium-sized Israeli manufacturers. Journal of Global Marketing, 2(2), 27-51.

Javalgi, R. R. G., \& Todd, P. R. (2011). Entrepreneurial orientation, management commitment, and human capital: The internationalization of SMEs in India. Journal of Business Research, 64(9), 1004-1010.

Johanson, J. and J-E Vahlne (1990). The mechanism of internationalization, International Marketing Review, 7(4), 11-24.

Johanson, J., \& Vahlne, J. E. (2009). The Uppsala internationalization process model revisited: From liability of foreignness to liability of outsidership. Journal of International Business Studies, 40(9), 1411-1431.

Johanson, J., \& Wiedersheim-Paul, F. (1975). The internationalization of the firm-four Swedish cases 1. Journal of Management Studies, 12(3), 305-323.

Jones, M. V., \& Coviello, N. E. (2005). Internationalisation: conceptualising an entrepreneurial process of behaviour in time. Journal of International Business Studies, 36(3), 284-303.

Jones, M. V., Coviello, N., \& Tang, Y. K. (2011). International entrepreneurship research (19892009): a domain ontology and thematic analysis. Journal of Business Venturing, 26(6), 632-659. 
Kalinic, I., Sarasvathy, S.D., \& Forza, C. (2014). Expect the Unexpected': Implications of Effectual Logic on the Internationalization Process. International Business Review, 23 (3), 63547.

Kamakura, W. A., Ramón-Jerónimo, M. A., \& Gravel, J. D. V. (2012). A dynamic perspective to the internationalization of small-medium enterprises. Journal of the Academy of Marketing Science, 40(2), 236-251.

Katz, D. and R. L. Kahn. (1978), The Social Psychology of Organizations. Wiley, New York.

Kim, M. (2013). Many roads lead to Rome: Implications of geographic scope as a source of isolating mechanisms. Journal of International Business Studies, 44(9), 898-921.

Knight, G. A. and Cavusgil, S. T. (1996), The born global firm: a challenge to traditional internationalization theory, in S.T. Cavusgil and T. Madsen (Eds.) Advances in International Marketing, Vol. 8, JAI Press, Greenwich, CT, 11-26.

Knight, G. A., \& Cavusgil, S. T. (2004). Innovation, organizational capabilities, and the bornglobal firm. Journal of International Business Studies, 35(2), 124-141.

Knight, G., Madsen, T., \& Servais, P. (2004). An inquiry into born-global firms in Europe and the USA. International Marketing Review, 21(6), 645-665 
Kontinen, T. \& Ojala, A. (2011a). International opportunity recognition among small and medium-sized family firms. Journal of Small Business Management, 49(3), 490-514.

Kontinen, T., \& Ojala, A. (2011b). Network ties in the international opportunity recognition of family SMEs. International Business Review, 20(4), 440-453.

Kuivalainen, O., Sundqvist, S., \& Servais, P. (2007). Firms' degree of born-globalness, international entrepreneurial orientation and export performance. Journal of World Business, 42(3), 253-267.

Leonidou, L. C. (1995). Export stimulation research: review, evaluation and integration. International Business Review, 4(2), 133-156.

Leonidou, L. C., Katsikeas, C. S., Palihawadana, D., \& Spyropoulou, S. (2007). An analytical review of the factors stimulating smaller firms to export: Implications for policy-makers. International Marketing Review, 24(6), 735-770.

Lopez, L. E., Kundu, S. K., \& Ciravegna, L. (2009). Born global or born regional\&quest; Evidence from an exploratory study in the Costa Rican software industry. Journal of International Business Studies, 40(7), 1228-1238. 
Lu, Y., Zhou, L., Bruton, G., \& Li, W. (2010). Capabilities as a mediator linking resources and the international performance of entrepreneurial firms in an emerging economy. Journal of International Business Studies, 41(3), 419-436.

Lyon, D. W., Lumpkin, G. T., \& Dess, G. G. (2000). Enhancing entrepreneurial orientation research: Operationalizing and measuring a key strategic decision making process. Journal of management, 26(5), 1055-1085.

MarketLine (2017, June). Industry Profile: Global Software. London, UK: MarketLine.

Matthews, J. A., and I. Zander (2007). The international entrepreneurial dynamics of accelerated internationalization. Journal of International Business Studies 38(3), 387-403.

McDougall, P. P., \& Oviatt, B. M. (2000). International entrepreneurship: the intersection of two research paths. Academy of Management Journal, 43(5), 902-906.

Misangyi, V. F., Greckhamer, T., Furnari, S., Fiss, P. C., Crilly, D., \& Aguilera, R. (2017). Embracing causal complexity: The emergence of a neo-configurational perspective. Journal of Management, 43(1), 255-282.

Mitchell, R. K., Busenitz, L. W., Bird, B., Marie Gaglio, C., McMullen, J. S., Morse, E. A., \& Smith, J. B. (2007). The central question in entrepreneurial cognition research. Entrepreneurship Theory and Practice, 31(1), 1-27. 
Nummela, N., Saarenketo, S., Jokela, P., \& Loane, S. (2014). Strategic Decision-Making of a Born Global: A Comparative Study from Three Small Open Economies. Management International Review, 54 (4), 527-50.

Ogram, E. W. (1982). Exporters and non-exporters: a profile of small manufacturing firms in Georgia. Export management: An international context, 70-84.

Ojala, A., \& Tyrväinen, P. (2007). Market entry and priority of small and medium-sized enterprises in the software industry: An empirical analysis of cultural distance, geographic distance, and market size. Journal of International Marketing, 15(3), 123-149.

Ojala, A. (2009). Internationalization of knowledge-intensive SMEs: The role of network relationships in the entry to a psychically distant market. International Business Review, 18(1), $50-59$.

Omorede, A., Thorgren, S., \& Wincent, J. (2014). Entrepreneurship psychology: a review. International Entrepreneurship and Management Journal, 1-26.

Oviatt, B. M., \& McDougall, P. P. (1994). Toward a theory of international new ventures. Journal of International Business Studies, 45-64. 
Oviatt, B. M., \& McDougall, P. P. (2005). Defining international entrepreneurship and modeling the speed of internationalization. Entrepreneurship Theory and Practice, 29(5), 537-554.

Podsakoff, P. M., MacKenzie, S. B., Lee, J-Y., \& Podsakoff, N. P. 2003. Common method biases in behavioral research: A critical review of the literature and recommended remedies. Journal of Applied Psychology, 88(5): 879-903.

Porter, M. (1979). The structure within industries and companies' performance. The Review of Economics and Statistics, 61, 214-227.

Porter, M. E., \& Ketelhöhn, N. W. (2002). Building a cluster: electronics and information technology in Costa Rica. Harvard Business School.

Prashantham, S. (2011). Social capital and Indian micromultinationals. British Journal of Management, 22(1), 4-20.

Ragin, C. C. (2006). Set relations in social research: Evaluating their consistency and coverage. Political Analysis, 14(3), 291-310.

Ragin, C. C. (2008), Redesigning Social Inquiry: Fuzzy Sets and Beyond. University of Chicago Press, Chicago. 
Ragin, C. C., \& Pennings, P. (2005). Fuzzy sets and social research. Sociological Methods \& Research, 33(4), 423-430.

Reid, S. D. (1981). The decision-maker and export entry and expansion. Journal of International Business Studies, 12(2), 101-112.

Reuber, A. R, Dimitratos, P., \& Kuivalainen O. (2017). Beyond categorization: New directions for theory development about entrepreneurial internationalization. Journal of International Business Studies, 48: 411-422.

Rialp, A., Rialp, J., \& Knight, G. A. (2005). The phenomenon of early internationalizing firms: what do we know after a decade (1993-2003) of scientific inquiry? International Business Review, 14(2), 147-166.

Rihoux, B., \& Ragin C.C. (2009), Configurational Comparative Methods: Qualitative Comparative Analysis (QCA) and Related Techniques, Applied Social Research Methods Series, 51. Sage, Thousand Oaks, CA.

Rugman, A. M., Verbeke, A., \& Nguyen, P. C. Q. T. (2011). Fifty years of international business theory and beyond. Management International Review, 51(6), 755-786.

Shepherd, D. A., \& DeTienne, D. R. (2005). Prior knowledge, potential financial reward, and opportunity identification. Entrepreneurship Theory and Practice, 29(1), 91-112. 
Shrader, R. C., Oviatt, B. M., \& McDougall, P. P. (2000). How new ventures exploit trade-offs among international risk factors: Lessons for the accelerated internationization of the 21st century. Academy of Management journal, 43(6), 1227-1247.

Sommer, L. (2010). Internationalization processes of small-and medium-sized enterprises-a matter of attitude? Journal of International Entrepreneurship, 8(3), 288-317.

Sommer, L., \& Haug, M. (2011). Intention as a cognitive antecedent to international entrepreneurship—understanding the moderating roles of knowledge and experience. International Entrepreneurship and Management Journal, 7(1), 111-142.

Tsang, E. W. (2013). Case study methodology: causal explanation, contextualization, and theorizing. Journal of International Management, 19(2), 195-202.

Tuppura, A., Saarenketo, S., Puumalainen, K., Jantunen, A., \& Kyläheiko, K. (2008). Linking knowledge, entry timing and internationalization strategy. International Business Review, 17(4), 473-487.

Villalobos, V., \& Monge-González, R. (2011). Costa Ricas efforts toward an innovation-driven economy: The role of the ICT sector. The Global Information Technology Report 2010-2011, $119-126$. 
Von Bertalanffy, L. (1968), General System Theory: Foundations, Development, Applications (Revised edition), George Braziller Inc., New York.

Welch, C., Piekkari, R., Plakoyiannaki, E., \& Paavilainen-Mäntymäki, E. (2011). Theorising from case studies: Towards a pluralist future for international business research. Journal of International Business Studies, 42(5), 740-762.

Westhead, P., Wright, M., \& Ucbasaran, D. (2001). The internationalization of new and small firms: A resource-based view. Journal of Business Venturing, 16(4), 333-358.

Witt, M. A., \& Jackson, G. (2016). Varieties of capitalism and institutional comparative advantage: A test and reinterpretation. Journal of International Business Studies, 47(7), 778-806.

World Bank Group (2006). “Costa Rica Country Economic Memorandum: The Challenges for Sustained Growth” Report No.36180-CR. Washington, D.C: Poverty Reduction and Economic Management Sector Unit, Central America Country Management Unit, Latin America and the Caribbean Region, World Bank.Available at:

[http://siteresources.worldbank.org/INTCOSTARICA/Resources/CR_Country_Economic_Memo randum_2006.pdf]. Accessed Oct. 3, 2015

Zahra, S. A., Ireland, R. D., \& Hitt, M. A. (2000). International expansion by new venture firms: International diversity, mode of market entry, technological learning, and performance. Academy of Management journal, 43(5), 925-950. 
Zahra, S. A., Korri, J. S., \& Yu, J. (2005). Cognition and international entrepreneurship: implications for research on international opportunity recognition and exploitation. International business review, 14(2), 129-146.

Zahra, S. A., Neubaum, D. O., \& Huse, M. (1997). The effect of the environment on export performance among telecommunications new ventures. Entrepreneurship Theory and Practice, $22,25-46$.

Zucchella, A., Danicolai, S., \& Palamara, G. (2007). The drivers of the early internationalization of the firm. Journal of World Business, 42 (3), 268-280. 
Figure 1. A priori conceptual model - factors leading to early internationalization

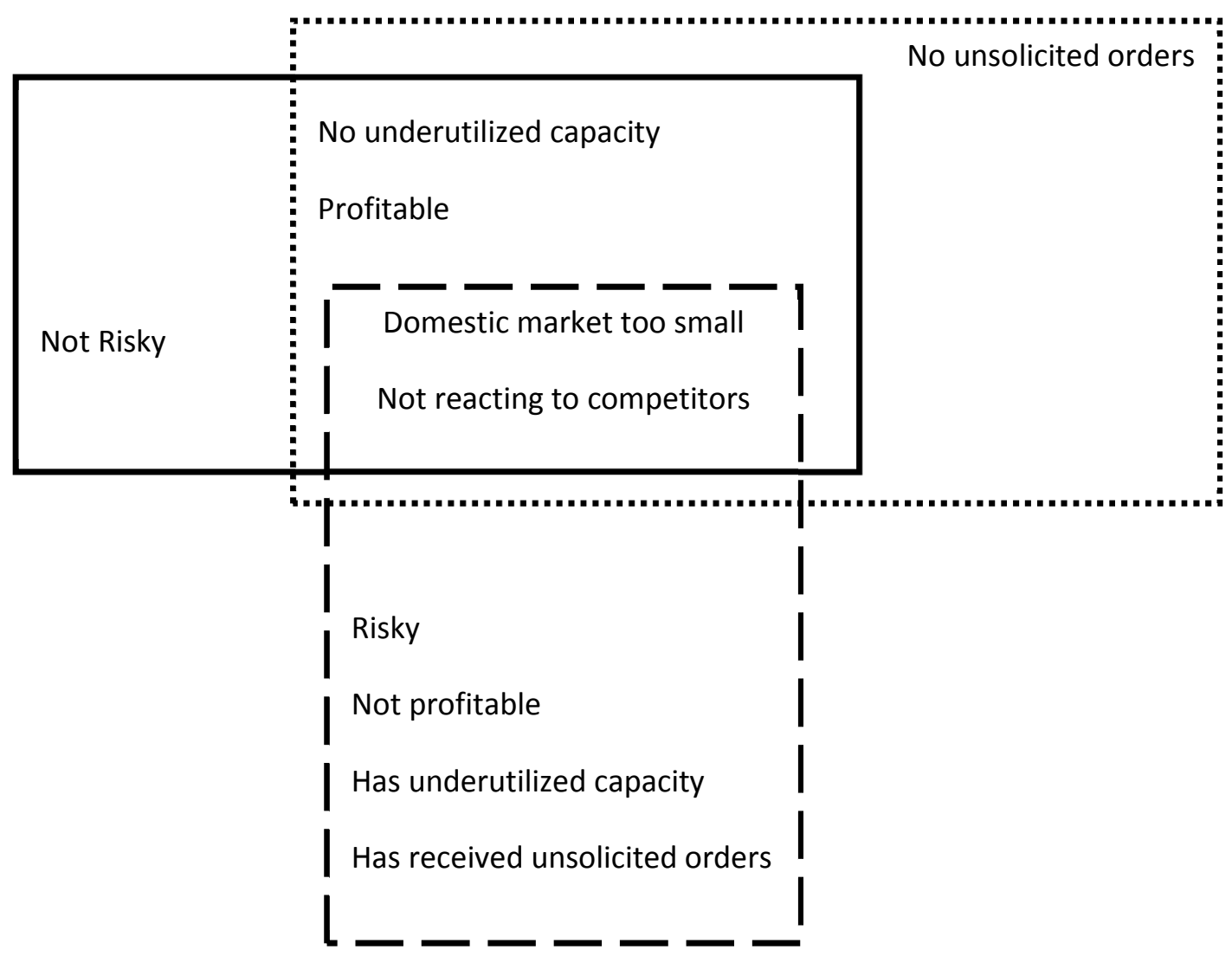

Note: Entrepreneurial (attitudinal) antecedents: Attitude toward risk, Attitude toward the profitability of export markets, Attitude toward the size of the domestic market

Resource-based antecedents: Underutilized capacity (availability of extra organizational resources)

Market-based antecedents: Competitor behavior (need to internationalize as a way to either anticipate or respond to competitors' behavior), Unsolicited orders 
Figure 2. Venn diagram

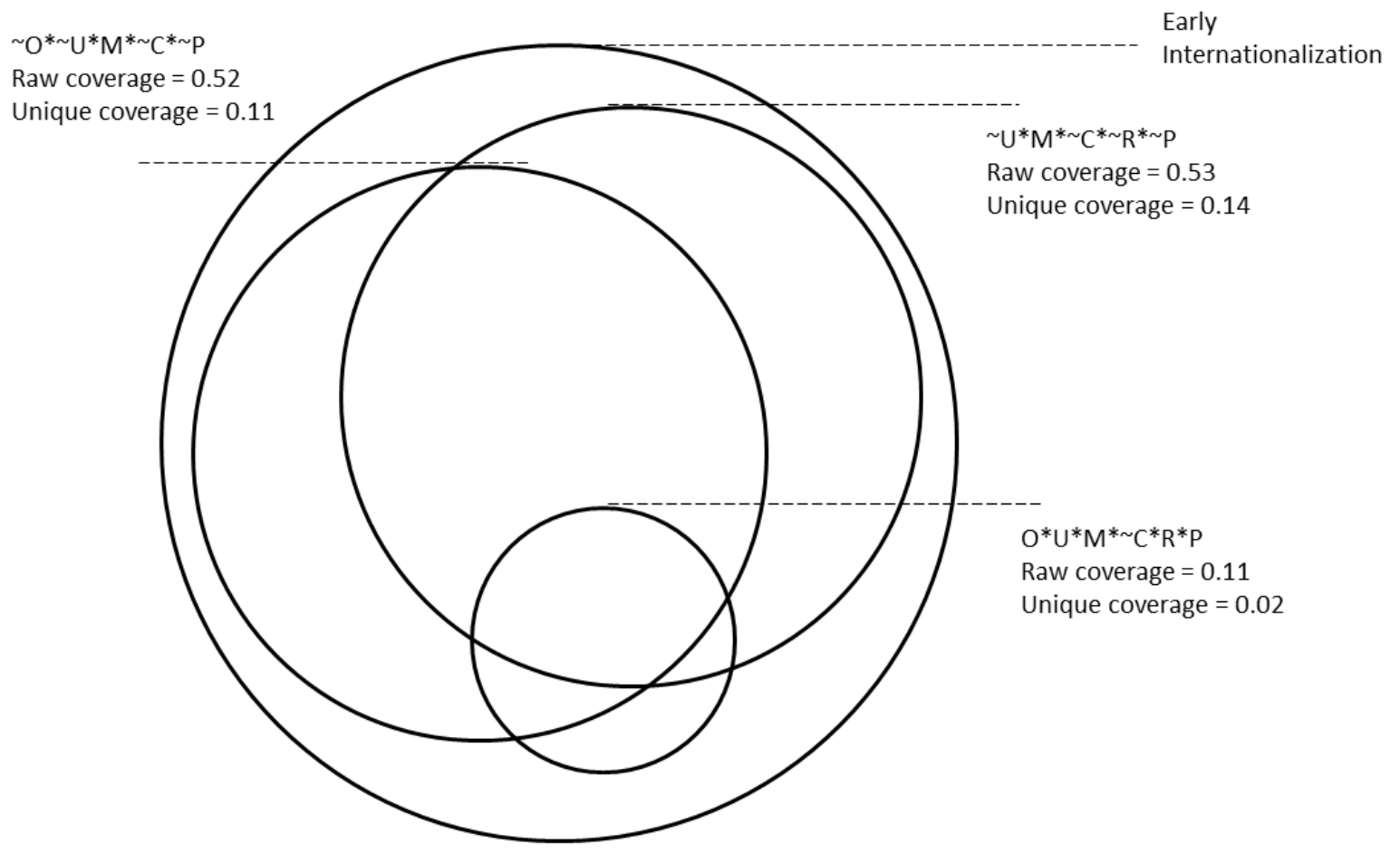

Venn diagram of the partitioning of set-theoretic coverage of early internationalization using fuzzy sets. O: Unsolicited order; C: Exports by competitor; M: Small domestic market; U: Underutilized capacity; R: Export markets risky; P: Export markets not profitable.

Note: stands for negation. 
Table 1

Descriptive information on the respondent firms

\begin{tabular}{|c|c|c|c|c|c|c|}
\hline \multirow[t]{2}{*}{ Firm } & \multirow{2}{*}{$\begin{array}{l}\text { Size } \\
\text { (number } \\
\text { of } \\
\text { employees } \\
\text { category) }\end{array}$} & \multirow{2}{*}{$\begin{array}{l}\text { First market } \\
\text { entered }\end{array}$} & \multicolumn{3}{|c|}{ Percentage of Customers Located } & \multirow{2}{*}{$\begin{array}{l}\text { Time to } \\
\text { First } \\
\text { Export } \\
\text { (years) }\end{array}$} \\
\hline & & & $\begin{array}{l}\text { Within } \\
\text { Country }\end{array}$ & Regional & International & \\
\hline 1 & 5 & Guatemala & $40.0 \%$ & $30.0 \%$ & $30.0 \%$ & 6 \\
\hline 2 & 4 & USA & $15.0 \%$ & $0.0 \%$ & $85.0 \%$ & 0 \\
\hline 3 & 1 & Canada & $96.0 \%$ & $2.0 \%$ & $2.0 \%$ & 3 \\
\hline 4 & 4 & Panama & $95.0 \%$ & $5.0 \%$ & $0.0 \%$ & 17 \\
\hline 5 & 4 & Dominican Rep. & $5.0 \%$ & $0.0 \%$ & $95.0 \%$ & 2 \\
\hline 6 & 1 & Central America & N/A & N/A & N/A & 1 \\
\hline 7 & 3 & Dominican Rep. & $85.0 \%$ & $7.5 \%$ & $7.5 \%$ & 4 \\
\hline 8 & 2 & Venezuela & $60.0 \%$ & $20.0 \%$ & $20.0 \%$ & 2 \\
\hline 9 & 2 & Dominican Rep. & $65.0 \%$ & $30.0 \%$ & $5.0 \%$ & 6 \\
\hline 10 & 4 & El Salvador & $50.0 \%$ & $50.0 \%$ & $0.0 \%$ & 13 \\
\hline 11 & 1 & Central America & $20.0 \%$ & $40.0 \%$ & $40.0 \%$ & 4 \\
\hline 12 & 2 & Panama & $85.0 \%$ & $5.0 \%$ & $10.0 \%$ & 0 \\
\hline 13 & 4 & El Salvador & $20.0 \%$ & $10.0 \%$ & $70.0 \%$ & 5 \\
\hline 14 & 2 & USA & $80.0 \%$ & $10.0 \%$ & $10.0 \%$ & 2 \\
\hline 15 & 1 & Nicaragua & $90.0 \%$ & $10.0 \%$ & $0.0 \%$ & 10 \\
\hline 16 & 4 & El Salvador & $20.0 \%$ & $60.0 \%$ & $20.0 \%$ & 2 \\
\hline 17 & 5 & Venezuela & $42.0 \%$ & $31.0 \%$ & $27.0 \%$ & 2 \\
\hline
\end{tabular}




\begin{tabular}{|c|c|c|c|c|c|c|}
\hline 18 & 1 & Central America & $2.5 \%$ & $15.0 \%$ & $82.5 \%$ & 0 \\
\hline 19 & 2 & $\begin{array}{l}\text { Central \& South } \\
\text { America }\end{array}$ & $95.0 \%$ & $3.0 \%$ & $2.0 \%$ & 4 \\
\hline 20 & 2 & Mexico & $50.0 \%$ & $50.0 \%$ & $0.0 \%$ & 0 \\
\hline 21 & 3 & Central America & $70.0 \%$ & $30.0 \%$ & $0.0 \%$ & 4 \\
\hline 22 & 5 & Nicaragua & $1.0 \%$ & $25.0 \%$ & $74.0 \%$ & 2 \\
\hline 23 & 2 & El Salvador & $85.0 \%$ & $10.0 \%$ & $5.0 \%$ & 7 \\
\hline 24 & 1 & USA & $90.0 \%$ & $10.0 \%$ & $0.0 \%$ & 4 \\
\hline 25 & 4 & Mexico & $80.0 \%$ & $10.0 \%$ & $10.0 \%$ & 3 \\
\hline 26 & 2 & Ecuador & $10.0 \%$ & $10.0 \%$ & $80.0 \%$ & 1 \\
\hline 27 & 2 & Mexico & $90.0 \%$ & $5.0 \%$ & $5.0 \%$ & 0 \\
\hline 28 & 2 & Ecuador & $70.0 \%$ & $10.0 \%$ & $20.0 \%$ & 2 \\
\hline 29 & 1 & Nicaragua & $90.0 \%$ & $10.0 \%$ & $0.0 \%$ & 7 \\
\hline
\end{tabular}

Note: Number of Employees: $1=0$ to 10 employees; $2=11$ to 25 employees; $3=26-50$ employees; $4=$

51 to 100 employees; 5 = over 100 employees. In the cases where "Central America" is given as a first market, the respondents did not wish to specify in which country they first entered. However, they confirmed that their first international market entry was into one of the countries of Central America, which they identified as El Salvador, Honduras, Guatemala, Nicaragua, Panama (and Costa Rica, but in this case, it is excluded because it is the country of origin of the focal firms). 
Table 2

Spearman rank correlation coefficients and descriptive statistics for variables $(n=29)$

\begin{tabular}{|c|c|c|c|c|c|c|c|}
\hline & TTFE & $\mathbf{O}$ & $\mathbf{U}$ & $\mathbf{M}$ & $\mathbf{C}$ & $\mathbf{R}$ & $\mathbf{P}$ \\
\hline $\mathbf{O}$ & 0.007 & & & & & & \\
\hline $\mathbf{U}$ & -0.001 & 0.056 & & & & & \\
\hline $\mathbf{M}$ & -0.012 & 0.050 & $-0.360 \dagger$ & & & & \\
\hline $\mathbf{C}$ & -0.009 & $-0.430 *$ & -0.088 & 0.024 & & & \\
\hline $\mathbf{R}$ & -0.081 & -0.250 & 0.252 & -0.055 & 0.024 & & \\
\hline$\overline{\mathbf{P}}$ & 0.210 & 0.001 & 0.189 & -0.170 & 0.031 & $0.438 *$ & \\
\hline Mean & 3.90 & 4.52 & 3.03 & 7.83 & 2.97 & 2.62 & 1.48 \\
\hline S.D. & 3.97 & 2.76 & 1.72 & 1.81 & 1.45 & 1.59 & 0.91 \\
\hline TTFE & \multicolumn{7}{|c|}{ Time to first export (outcome) } \\
\hline $\mathrm{O}$ & \multicolumn{7}{|c|}{ Reception of unsolicited orders } \\
\hline $\mathrm{U}$ & \multicolumn{7}{|c|}{ Existence of underutilized capacity } \\
\hline $\mathrm{M}$ & \multicolumn{7}{|c|}{ Small market size } \\
\hline $\mathrm{C}$ & \multicolumn{7}{|c|}{ Competitor behavior } \\
\hline $\mathrm{R}$ & \multicolumn{7}{|c|}{ Perceptions of risk } \\
\hline $\bar{P}$ & \multicolumn{7}{|c|}{ Perceptions of profitability } \\
\hline S.D. & \multicolumn{7}{|c|}{ Standard deviation } \\
\hline$* * p<0$ & $0<0.05$ & & & & & & \\
\hline
\end{tabular}




\section{Table 3}

Test of necessary antecedents of early internationalization

\begin{tabular}{|lcc|}
\hline Antecedent & Consistency & Coverage \\
\hline Unsolicited order: $\mathrm{O}$ & 0.27 & 0.79 \\
\hline Underutilized capacity: U & 0.25 & 0.84 \\
\hline Small domestic market: M & 0.94 & 0.80 \\
\hline Exports by competitor: C & 0.51 & 0.81 \\
\hline Export markets risky: R & 0.47 & 0.81 \\
\hline Export markets not profitable: P & 0.18 & 0.84 \\
\hline R+P & 0.47 & 0.81 \\
\hline$\sim \mathrm{R}+\mathrm{P}$ & 0.91 & 0.76 \\
\hline
\end{tabular}

Note: stands for negation. 


\section{Table 4}

\section{Consistency and coverage of the configurations}

\begin{tabular}{|lllll|}
\hline & Configuration & Raw Coverage & Unique Coverage & Consistency \\
\hline I. & $\sim \mathbf{U}^{*} \mathbf{M}^{*} \sim \mathbf{C}^{*} \sim \mathbf{R}^{*} \sim \mathbf{P}$ & 0.53 & 0.14 & 0.85 \\
\hline II. & $\sim \mathbf{O} * \mathbf{U} * \mathbf{M} * \mathbf{C} * \mathbf{P}$ & 0.52 & 0.11 & 0.91 \\
\hline III. & $\mathbf{O} * \mathbf{U}^{*} \mathbf{M}^{*} \sim \mathbf{C}^{*} \mathbf{R} * \mathbf{P}$ & 0.11 & 0.02 & 0.97 \\
\hline
\end{tabular}

Note: stands for negation. O: Unsolicited order, U: Underutilized capacity, M: Small domestic market, C: Competitor behaviour, R: Export markets risky, P: Export markets not profitable 
Table 5

Three configurations leading to early internationalization

\begin{tabular}{|c|c|c|c|c|c|c|}
\hline & $\begin{array}{l}\text { Reception of } \\
\text { Unsolicited } \\
\text { Orders }\end{array}$ & $\begin{array}{l}\text { Underutilized } \\
\text { Capacity }\end{array}$ & $\begin{array}{l}\text { Attitude } \\
\text { toward the } \\
\text { Size of the } \\
\text { Domestic } \\
\text { market }\end{array}$ & $\begin{array}{l}\text { Behavior of } \\
\text { Competitors }\end{array}$ & $\begin{array}{l}\text { Attitude } \\
\text { toward } \\
\text { Risk of } \\
\text { Exporting }\end{array}$ & $\begin{array}{l}\text { Attitude } \\
\text { toward } \\
\text { Profitability } \\
\text { of Exporting }\end{array}$ \\
\hline $\begin{array}{l}\text { Configuration } \\
\text { I }\end{array}$ & $\begin{array}{l}\text { Not Relevant for } \\
\text { the Outcome }\end{array}$ & $\begin{array}{l}\text { No } \\
\text { Underutilized } \\
\text { Capacity }\end{array}$ & $\begin{array}{l}\text { Domestic } \\
\text { Market Too } \\
\text { Small }\end{array}$ & $\begin{array}{l}\text { Not Reacting } \\
\text { to } \\
\text { Competitors' } \\
\text { Behavior }\end{array}$ & Not Risky & Profitable \\
\hline $\begin{array}{l}\text { Configuration } \\
\text { II }\end{array}$ & $\begin{array}{l}\text { No Unsolicited } \\
\text { Orders Received }\end{array}$ & $\begin{array}{l}\text { No } \\
\text { Underutilized } \\
\text { Capacity }\end{array}$ & $\begin{array}{l}\text { Domestic } \\
\text { Market Too } \\
\text { Small }\end{array}$ & $\begin{array}{l}\text { Not Reacting } \\
\text { to } \\
\text { Competitors' } \\
\text { Behavior }\end{array}$ & $\begin{array}{l}\text { Not } \\
\text { Relevant for } \\
\text { the } \\
\text { Outcome* }\end{array}$ & Profitable \\
\hline $\begin{array}{l}\text { Configuration } \\
\text { III }\end{array}$ & $\begin{array}{l}\text { Has Received } \\
\text { Unsolicited } \\
\text { Orders }\end{array}$ & $\begin{array}{l}\text { Has } \\
\text { Underutilized } \\
\text { Capacity }\end{array}$ & $\begin{array}{l}\text { Domestic } \\
\text { Market Too } \\
\text { Small }\end{array}$ & $\begin{array}{l}\text { Not Reacting } \\
\text { to } \\
\text { Competitors' } \\
\text { Behavior }\end{array}$ & Risky & Not Profitable \\
\hline
\end{tabular}

*When an antecedent is "not relevant for the outcome," it means that whether or not such an antecedent is present has no effects on the outcome. For example, in this case, whether the entrepreneur considers internationalizing to be risky or not does not affect the speed of internationalization. 


\section{Appendix 1}

\section{Consistency and Coverage Indicators When Testing for Necessity}

The consistency score is given in equation App1-1:

Consistency $(\mathrm{Xi} \leq \mathrm{Yi})=\sum_{i=1}^{C} \min (\mathrm{Xi}, \mathrm{Yi}) / \sum_{i=1}^{C} \mathrm{Yi} . \quad(\mathrm{App} 1-1)$

The coverage rate of an antecedent $\mathrm{Xi}$ or a combination of antecedents necessary for the outcome is given in equation App1-2:

Coverage $(\mathrm{Yi} \leq \mathrm{Xi})=\sum_{i=1}^{C} \min (\mathrm{Xi}, \mathrm{Yi}) / \sum_{i=1}^{C} \mathrm{Xi} . \quad($ App1-2)

$\mathrm{Xi}$ represents membership scores in a combination of antecedents, Yi represents membership scores in the outcome, and $\mathrm{C}$ is the number of cases.

\section{Appendix 2}

\section{Consistency and Coverage Indicators When Testing for Sufficiency}

In dealing with sufficiency, consistency is given by (Ragin, 2006)

Consistency $(\mathrm{Xi} \leq \mathrm{Yi})=\sum_{i=1}^{C} \min (\mathrm{Xi}, \mathrm{Yi}) / \sum_{i=1}^{C} \mathrm{Xi}$,

and coverage is given by (Ragin, 2006)

Coverage $(\mathrm{Xi} \leq \mathrm{Yi})=\sum_{i=1}^{C} \min (\mathrm{Xi}, \mathrm{Yi}) / \sum_{i=1}^{C} \mathrm{Yi}$.

$\mathrm{Xi}$ represents membership scores in a combination of antecedents, Yi represents membership scores in the outcome, and $\mathrm{C}$ is the number of cases. 